O. Lisnichenko,

$P h D$ in Economics, Associate Professor of the Department of Commodity, quality management and environmental safety, Kharkiv State University of Nutrition and Trade

DOI: $10.32702 / 2306-6806.2018 .12 .25$

\title{
EVOLUTION OF THE CONCEPT OF HUMAN CAPITAL
}

\section{О. О. Аісніченко,}

к. е. н., доцент кафедри товарознавства, управління якістю та екологічної безпеки,

Харківський державний університет харчування та торгівлі

\section{ЕВОАЮЦІЯ КОНЦЕПЦІЇ "АЮАСЬКОГО КАПІТААУ"}

The sources of interpretation of the scientific category "human capital"are investigated. Its definition was laid by the philosophers of antiquity. It was established that the attempt of the first scientific interpretation of the concept, as a separate component, was made by the ancient Greek philosopher Aristotle. He defined it as a driving force, which was aimed on obtaining a material benefit. This benefit had to be fairly divided among all members of society in accordance with the results of their work. During the Middle Ages thinkers made an attempt to reveal this issue in the "work-benefit" plane.

It was established that the thoughts of thinkers of the New time became the basis of modern interpretation of this concept They revealed this definition in the context of the development of capitalist relations, which were based on the explanation of human capital as a result of the synthesis of natural resources and labor. It is stated that the modern scientific substantiation of this category was made in the middle of the twentieth century. It explained the essence of this category at the scientific theoretical level, which has a close connection with the natural desires of man and the skills that he receives during the period of receiving education and profession, and also has a close connection with the formation and support of a strong worker's health.

It is noted that according to modern researchers the employer can receive a skilled worker only in the presence of the above factors. The worker will produce quality products that will bring a profit to the employer and high wages to him. It is also noted that fundamental research in this area is urgent today for the complete and thorough definition of this scientific definition at the scientific and theoretical level and finding the optimal ways of developing capitalist relations in the enterprise for optimizing technological processes in production and increasing their profitability.

Аосліджуються витоки трактування наукової категорії "Аюдський капітал", визначення котрої було ще закАадено філософами античності. ВСтановлено, що спроба першого наукового трактування поняття, як окремої СКАадової було зроблемнодавньогрецьким філософомАристотелем, котрий визначав його як рушійнУ Силу, котра має на меті отримання матеріального блага, яке повинно було справедливо поділене між всіма членами соціуму відповіднодо результатів зробленої ними роботи. Уперіод Середньовіччя мислителями була зроблена Спроба розкрити дане питання у площині "робота-благо". ВСтановлено, що оновою сучасного трактування цього поняття Стали роздуми мислителів Нового часу, котрі розкривали дану дефініцію у руслі розвитку капіталіСтичних відносин, котре грунтувалося на поясненні Аюдського капіталу як результату СинтезУ природніх задатків та праці. Констатується, що сучасне наукове обгрунтування такої категорії було оформдене у сер. $X X$ СТ, яке пояснило на науково-теоретичному рівні, його сутність, котра має тісний зв 'язок з прродними (УроАженими) задатками Аюдини та навичками, котрі вона отримує У період опанування освіти та професійного фаху, а також має тісний зв 'язок з формуванням та під тримкою міцного здоров 'я робітника. Зауважується, що, на думкУ СУчасних, ослідників, дише за наявності вищеокреслених чинників, можАиве отримання роботодавцем квалірікованого робітника, котрий буде виробляти якісну продукцію, що буде приносити, роботодавцю - прибуток, а робітнику - високу оплату праці. Зауважується, що на Сьогодні актуальним залишаєтьСя проведення фундаментального дослідження у цій царині за для повноцінного та грунтовного означення такої на укової дефініції на науково-теоретичному рівні та знаходження оптимальних шляхів розвитку капіталістичних відносин на підприємстві за дяя оптимізації технологічних процесів на виробництві та збільшення їх прибутковості.

Key words: wealth, resource, capital, society, capitalism, labour payment, factor, concept.

Ключові слова: благо, ресурс, капітал, суспільство, капіталізм, оплата прачі, чинник, кониепчіл.

\section{PROBLEM STATEMENT}

The theoretical foundations of the definition of the scientific category "human capital" have attracted more attention in recent times. Studying the theoretical aspects of this problem is acquiring significant development. Scientific theories for its definition are forming. Approaches for attraction theoretical knowledge to the practical plane are being developed at the practical level, in particular for 
the modernization of labor resources management. However, the design of significant levers of human capital management will be impossible without a complete scientific and theoretical analysis of this issue through the prism of scientific views, which were historically formed under the influence of various historical processes. In our opinion it is the key to developing an optimal strategy for managing labour resources at a modern enterprise for increasing the efficiency of labour productivity and obtaining profits.

\section{ANALYSIS OF RECENT RESEARCH AND PUBLICATIONS}

It is worth noting that the problem of our research is based on the works of famous researchers, who are international authorities in this field, in particular: G. Becker, J. Kendrick, L. Turou, I. Fischer, T. Schultz, O. Dobrynina, S. Diatlov, V. Antoniuk, V. Blizniuk, D. Godin, O. Borodin, O. Grishnov, A. Kolot, N. Markova.

The objective of the article: the study of the evolution of the "human capital" category in the views of thinkers.

\section{PRESENTING OF THE MAIN MATERIAL}

Payment for the work has always been a lively scientific interest, and its interpretation as a scientific definition was originally of a secondary nature.It was associated with qualitative characteristics of potential labour opportunities. The theoretical basis for the study of human capital was laid in the works of ancient Greek thinkers, in particular, long before the appearance of the actual scientific substantiation the questions divoted to labor relations were disclosed by Xenophon and AristotleIn particular, Aristotle was the first who substantiated the concept of "capital". He identified an independent science of wealth, which depends on the accumulation of money and the proportional distribution of economic benefits. The thinker tries to explain the causality of the exchange of part of the good in part of another for the comparative proportional characteristics of them, because in his opinion, the benefits are proportional to the cost of labor to create them. The philosopher focuses on the complexity of all kinds of work, and therefore, he draws attention to the professional qualities of the worker who produces these benefits, because the higher the value of the good, the higher his professionalism and qualification [3].

Thinkers tried to investigate the role of human labour in the Middle Ages. The Arab philosopher Ibn Haldoun emphasized the genesis of value, stating that the greater the part of the accumulated is, the more it is beneficial to a person, and therefore it is equivalent to the value of labour. The thinker gives a special attention in his thoughts to the value of the contract of sale of "equal (equivalent) exchange by value" $[13$, p. $609-611]$, which is based on the idea of equalizing the equivalent amount of expenditures [14, p. 97].

Physiocrat F. Ken disclosed the concept of "capital" as having certain components of the group of "advances": capital in the form of "initial advances" consisting of animals, workplaces and tools of labour; "landowner advances", which included forms of optimizing the fertility of the land; and "annual advances", the basis of which was the payment of peasants' labor and expenditures that are repeated from year to year [4]. The thinker revealed the capital as a means by which a "pure product" was created [14, p. 166].

The position of classical economic school representatives about the problem of our study was based on the disclosure of capital, the basis of which is money or any other material value, as well as the qualifications of the employee. The significant role has been given to the interpretation of the concept of "human labour" in the views of V.Petti. Using comparative characteristics he indicated the amount of human labour, which is included in the price of manufactured goods. Also he defined the opposite of economic interests: workers, as a center of labour on the one hand and owners, as capital holders on the other [34,p.65]. According to the thinker, the productivity of labour opportunities is a determining factor in the economic prosperity of people. In particular, he stressed that: "It is better to burn the product of labour of one thousand people than to allow these people to do nothing and, as a result, lose their ability to work". In addition, V.Petti substantiated theoretically the method of indirect definition of the value of economic indicators. It should be noted his selective method which was quite accurate, even with a rather small amount of statistical data of that time. He managed to calculate accurately the national profits and income of England with the help of this technique for the first time in world practice. However, in our opinion it should also be noted that not only material components were included to the national income, but monetary simplicity of the population, which is the first in the history of the digital expression of human capital [1].

A. Smith defines capital as the main force of material wealth. Human capital has become a separate category of physical capital by his division along with machines designed to increase labour productivity; buildings where the process of capital formation is in progress; intruments that enhance the productivity of the land. Human capital was determined by the trait that everyone owns in society, which determines the costs and increases productivity [20, p. 177]. The thinker notes that "the worker's skill and ability can be treated in the same way as machines and implements of production, which reduce or facilitate labour, and although they require some expenses, but reimburse these costs along with profits" $[33$, p.171]. At the same time A. Smith makes a clear differentiation of wages because each job has specific features. Therefore, the more labour force is spent, the greater payment must be. In his opinion the material stimulation of the worker in the form of an allowance in payment is expedient if the worker showed his skills in the development of the final product. In particular, he states that "abilities and talents can rarely be gained in the absence of long previous exercises, and the higher value of their product is often only appropriate compensation of the time and labour that was required to be spent on their acquisition" [32]. That is, the thinker considered the work of people as the basis of material wealth of the state. It was positioned as a priority component of stability.

D. Ricardo characterized capital as a dominant sign of the development of the productive forces of society, in particular: "the part of the country's wealth, which is used in production and consists of food, clothing, tools, raw materials, machines - all that is necessary in order to bring labour in motion" [30, p. 455]. Also, D.Ricardo remarked that the land also forms the price of the produced goods, because the land rent is also due to the law of value, and therefore the increase in capital depends on the quality of work indicators that are human capital in essence, and therefore the person and his abilities are positioned as a pure capital.

As a result of this statement two positions were formed to explain the relation of a person with its abilities and capital. Representative of the first position - J.-S. Mill, J.B. This, A. Marshall and others. - rejected the position that people are associated as capital, considering that it is the ability of a person that he reveals in the process of developing a particular product. J.-B. Sei stressed that "man is not born with those abilities and forces that would be sufficient to perform even the easiest work. These abilities and forces can be considered as capital, which was formed by annual accumulation and a consistent increase in the cost of his education" [31, p. 59]. Analyzing the professional tasks of the man as the main driving force that affects its productivity, which in turn leads to the intensification of the production process, the thinker believed that the material resources that were skillfully invested in the worker for his education lead to the creation of a professional specialist who determines the accumulation of capital [31, p. 43]. 
J.S. Mill, studying the factors contributing to productivity, believed that the main of them are the employer and his manager's skills [27, p. 214]. Stressing at the same time that "I do not consider the very person as wealth. It is a goal for which wealth exists" [27,p.139]. M. Blaug treats capital as a result of investments invested in man [36]. The main thesis in this direction is the position of A. Marshall that makings are extremely important, since the motives "forcing a person to accumulate capital in his son's head in the process of learning" are the same as those who "manage him when pledging material capital for a son" $[25$, p. 79]. At the same time, the thinker considered the theory of "human capital" as well-founded. This statement became an established position up to the 50's - early 60's of the twentieth century [12].

In contrast, the neoclassical thinkers positioned the person with his abilities as capital in its pure form. For example, J.R. McCulloch thought this as fitting statement, because: "Instead of understanding capital as a part of industrial production, an intangible to a man, that could be used to support it and to promote production, there seems to be no valid reasons for which the man could not have taken it, and too much reasons why it can be considered as a part of the national wealth that is being formed" [41]. I. Fischer also held the same position defining capital as "a useful intended material object", and therefore the person who owns this feature should be an integral part of this concept and since a man possesses this characteristic, the sequence of reasoning requires including it in the concept of capital. Moreover, the skills of the individual are not an asset, but an addition to the individual. At the same time, the trained individual must be included in the capital" [17]. F. List, distinguishing categories of "property values" and "productive forces", placed the formation of human capital in the ways of constant mental searching in the first place. That is why the thinker provided the process of education and continuous improvement of the worker's skills in a significant role in these processes [14, p. 397].

We also consider it appropriate to stay on the position of Marxism on the topic of our study. From the interpretation of the position of capitalism, workers must constantly sell their own labour for paying for their own labour. The worker was presented as the carrier of the cost of labour in capitalized form.

K. Marx in his book "Capital" expresses the position of "useful work" spent during the year. "All these goods exist only because socially applied labour was spent in a diversified system of various types of useful labour. Therefore, in their total cost, the cost of the means of production spent on their production was preserved, appearing in the new one again" [23, p. 376]. The thinker adds: "Labour, which has a higher, more complex work than average social labour, is the display of a labour force that requires higher costs, the production of which requires more working time and has a higher cost than a simple workforce. If the value of this force is higher, it manifests itself in higher labour and is formed at equal intervals of time at relatively higher values" [19].

The thinker defines the natural abilities of the worker as "true wealth", "the main productive force of society". And because of it: "By labor force, or ability to work, we understand both physical and spiritual abilities, which an organism possesses, a living personality of a person, which he applies every time when he produces any consumer value" [24, p. 165].

In the process of scientific evolution, the category of "human capital", and indeed, the theory of human capital has become a complete and reasonable position only before the twentieth century. In particular, the scientific definition of "human capital" was introduced by F. Mahlup [26]. The researcher emphasizes the need to distinguish between innate and acquired abilities, because: "Improper work", he writes, "must be distinguished from the improved, which has become more productive due to investments that increase the physical and mental capacity of a person. Human capital is made up of such improvements" [40, p. 419]. That is why, capital is defined as a category of abilities that are formed during the learning process, which is divided into 8 groups: home education, school education, work experience, church regulations, training in the armed forces, education through television, self-education, knowledge of experience. However, we can note that this statement is still partially limited, since it is impossible to analyze it without a complete description of its relationship with other forms of abilities.

The generally accepted theory of "human capital" is the theory of T. Schulz and G. Becker. The first thinker stated that two determinants interact in the production process: the means of production and acquired skills used in the development of goods and services [12]. Giving the definition of "human capital" scholar T. Schultz disclosed it as the costs accumulated in the state for the reproduction of labour resources, and therefore it has features of a productive nature and has the property to reproduce constantly in a more qualitative form [5]. That is why the development of human capital lies in education, worker qualifications, sufficient medical support and a permanent stock of economic information [43, p. 64]. G. Becker stated that human capital is the identical form of material means of production, since it can be invested, through education, medicine, etc., and therefore the final result of the product development will be only dependent indirectly on a person. That is, human capital, positioned in this definition as a means of production, the investment of which leads to an increase in the final profit, and therefore it is variable, and can not be inherited or be donated. Therefore, the material side of capital does not have a uniform form. Education and spending on it, health insurance lead to increased productivity and increased profits, and therefore thinkers define these costs as investing in human capital, which is interpreted as "human capital", since workers can not be distanced from their skills either as well as financial and material assets $[29$, p. 6].

$\mathrm{G}$. Becker proves the close connection between human capital and the incomes of its carriers. Thus, investing in education, providing a high-quality health insurance system, gaining the profession, a person consciously increases his capital in the future [38].

This theory has been expanded by Kendrick, who said that human capital is a synthesis of accumulated human knowledge which is materializing in the production process [15]. Human capital "consists of the acquired knowledge, skills, motivation and energy that human beings have and can be used for a certain time in order to produce goods and services", said researcher W. Bowen, analyzing the issues of the genesis and development of human capital [39]. L. Turu, synthesizing the study of the problem of our research, has drawn up such definition of this category: "Human capital represents the people's ability to produce objects and to provide services" [44, p. 15]. That is, the classical tradition of recognizing the necessity of abilities is preserved in this scientific category. But the latter also highlights the genetically established economic ability, which "is not just another industrial investment that the individual possesses. Economic ability affects the productivity of all other investments" [44, p. 48]. There fore, in researcher's opinion the need for a close connection between productivity and accumulation of human capital, which "in essence are the common products of human activity for the maintenance of life", is important [44, p. 125].

E. Boyther, exploring the causes of the "German economic miracle" (the post-war rebirth of the West German economy), stated: "Providing the destruction of material capital and the preservation of the subjective knowledge of people, the accumulated knowledge in libraries and the understanding of their value managed to reproduce the lost capital in a relatively limited period of time" [44, p. 7]. The researcher believes that the right to 
own human capital is urgent, as it is the main precondition for the productive using of material capital.

He notes that the possession of human capital is much more important than the possession of material capital, since the former is a precondition for the skilled using of material capital; therefore, it is expedient to say that a person who is trying to increase his wealth must constantly invest in the development of his skills and abilities, not forgetting about his own health, the loss of which can lead to a loss of capital in general.

J. Dolan and D. Lindsay provide such a definition of the category of "human capital", in particular: "capital in the form of mental abilities obtained through formal education or through practical experience" [37, p. 256; 445].

However, it should be noted that not all scientific theories on the topic of our study, in particular, on the payment of labour, were formalized in full scientific concepts. In our opinion it predetermines a significant field for discussions on this issue today. This primarily concerns scientists from post-Soviet countries. However, it is necessary to stop on the works of some scientists, who define the stages of formation of the concept of human capital.

At the end of the twentieth century some Russian scientists, in particular M. Kritsky, R. Kapeliushnikov, S. Diatlov and A. Dobrynin have chosen the theory of human capital as the center of their own research.

M. Kritsky gives such definition of "human capital", in particular: "general concrete form of human life that assimilates previous forms (consumer and industrial) and is implemented as a result of the movement of human society to its present state" [9]. A. Dobrynin and S. Diatlov interpret the category of "human capital" as historically established kind of economic activity, in particular "human capital is a set of all attribute qualities and properties, production capabilities and strength, functional roles and forms, which are considered from the position of system integrity and adequate to the present state of society, [...] included in the system of market economy as the leading creative factor of social production" [10, p. 163].

That is why, according to scientists, the formation of human capital is only probable in a post-industrial society, in which the thirst for scientific knowledge and information that modernizes society is dominant. The category "human capital" is a two-component system. Its first part consists of productive forces. The second one is the potential investment of a man in himself, which will determine his material income in the future $[11$, p. $15 ; 76]$.

That is, synthesizing the concept of A. Dobrynin and S. Diatlov, it should be noted that: "Human capital is formed as a result of investment and is accumulated by a person as a certain stock of health, knowledge, skills, abilities and motivations. They are used purposefully in one or another spheres of social production and contribute to the growth of labour productivity and efficiency of production and thus affect the growth of earnings (income) of this person" [11, p. 26].

The position of R. Kapeliushnikov is progressive. He was the first in Russian science who outlined human capital from the standpoint of G. Bowen. In particular: "every stock of knowledge, abilities and motivations is capital, since their formation requires the diversion of funds to the detriment current consumption, but at the same time they serve as a source of increase in productivity and earnings in the future" [30, p. 287].

The study of this problem in Ukrainian science began at the end of the 90 -ies of the twentieth century. O. Grishnova outlined the "human capital" as a multi-level system, which consists of the micro level (work place), the macro level (the enterprise's potential of the country) and the mezzanine (world economy) [8]. She also substantiated the factors leading to the growth of "human capital".

In addition, it should be noted that other Ukrainian researchers, such as: V. Antoniuk, B. Blyzniuk, O. Borodin, E. Libanova, N. Markova, J. Poplavskaia, L. Semiv, S. Vov- kanych, A. Chukhno and others paid partly the attention to the interpretation of the levels of "human capital". Nevertheless, it must be noted that the actual study of this issue is fundamental to modern Ukrainian economic science. It is determined not only by the scientific theoretical but also by practical significance for the development of the national economy.

Therefore, outlining the distinctive features in the theoretical justification of the category of "human capital", it should be noted that scientists stand out two basic components in defining of human capital: intellectual (educational) and biological (health), sometimes adding psychological mental traits. In addition, there is a clear limitation of it only by economic component in the structure of using of human capital. That is the profit and growth of its profit. Therefore not all of the above mentioned scientific definitions are expedient in the management of human capital and its monitoring. It is explained by the lack of their main thing - the definition of the most significant definition of "capital", which is defined as the stock that carries income $[12 ; 42]$.

Therefore, we can give our definition of the category of "human capital", based on the theoretical and methodological approaches to the definition of physical capital, which is a well-defined definition. In particular, it is the potential cost of labour skills of the worker. It seeks to make a profit from his work by the owner of the enterprise. This definition is expedient because it retains two main categories - "man" and "capital", which is the fundamental basis for designing a scientific analysis of methods for assessing and monitoring the use of human capital and its regulation at various levels of social work.

\section{CONCLUSIONS}

The analysis of the genesis of the scientific and theoretical interpretation of the "human capital" category made it possible to disclose the evolution to its definition. In particular, it should be noted that a significant role in its scientific design was played by the development of capitalist relations. On the one hand they increase the efficiency of labour for higher profits and high-quality products under the influence of the needs of owners. On the other hand they formed a class of highly professional workers who have high payment. This led to the fact that this category became the theoretical basis for the execution of scientific sententions, which showed the interconnection between these processes at the theoretical level. That is why thinkers gradually modified the category of "work" into the category of "people's capital" by providing the decisive value of remuneration in the process of increasing performance indicators. As a result of long-term evolution, this concept received its own scientific definition, but it still needs to be stated that its methodological basis for assessing the value of a subject is controversial and requires a fundamental research.

Investigating the category of "human capital" on the basis of a systematic analysis of its key features that have emerged in modern science and have undergone gradual modifications and improvements, it should be noted that this problem remains controversial and requires further thorough scientific, theoretical and practical studies for the purposeful definition of this scientific category, which is decisive in the formation of capitalist relations at the present stage.

\section{Literature:}

1. Agapova I.I. History of Economic Thought: A Course in Lectures/ I.I. Agapova // Electronic library of Kniazev Moscow: EKMOS, 1998 [Electronic resource]. - Access mode: http: // ebk. net.ua/Book/IemAga pova/10.htm

2. Antoniuk V. Main directions of strengthening of socio-economic foundations of human capital formation in Ukraine / V. Antoniuk // Ukraine: aspects of labour. 2006. - No. 2. - P. 39-47. 
3. Aristotle: Works: in $4 \mathrm{v}$. / Ed. VF M. Asmus Moscow: Thought, 1976. - Vol. 1 [Electronic resource]. Access mode: http://qps.ru/4G38V

4. Berezin I. Essays on the History of Economic Thought / I. Berezin. - M .: RISK, 1993. - 102 p.

5. Bogdanovski V. Labour and Employment in Agriculture / V. Bogdanovski // Issues of Economics. 2005. - No. 6. - P. 72-83.

6. Borodin O. Human capital as the main source of economic growth/ O. Borodin // Economy of Ukraine. 2003. - No. 7. - P. 48-53.

7. Golovai N.M. Investments in human capital and wages: accounting aspect / N.M. Golovai// Formation of a market economy: col. of scientific works. Special issue "Human Resources Management: Problems of Theory and Practice". - K.: KNEU, 2007. - T. 1. Ch. $1 .-520$ p.

8. Grishnova O.A. Human Capital: Formation in the System of Education and Training / O.A. Grishnova - K.: Knowledge, KOO, 2001. - 256 p.

9. Deriabina M. Institutional Aspects of Post-Socialist Transitional Period/ M. Deriabina// Issues of Economics. - 2001. - No. 2. - P. 108-114.

10. Dobrynin A.I. Man's productive forces: structure and forms of manifestation / A.I. Dobrynin, S.A. Diatlov, V..A Konnov, S.A. Kurganskyi - SPb., 1999. - 209 p.

11. Diatlov S.A. Fundamentals of the theory of human capital / S.A. Diatlov - SPb, 1994. - 154 p.

12. Economic Encyclopedia: in 3 v. T. 3 / Redcorn. S.V. Mochernyi (resp.ed.) [And others]. - K .: Akademiya, 2002. - $952 \mathrm{p}$

13. Selected works of thinkers of the Middle and Middle East IX-XIV centuries. / Ed. S.N. Grigorian - Moscow: Sotsekgiz, 1961. - $634 \mathrm{~s}$.

14. History of Economic Studies: [textbook]: in 2 p. P. 1 / Ed. V.D. Bazilevich; 2nd edition., corrected. - K.: Knowledge, 2008. - 567 pp

15. Kendrick J. Total US Capital and its Formation / J. Kendrick; commonly Ed. A.I. Anchishkin - M .: Progres, 1978 . - $275 \mathrm{p}$.

16. Kirian T. Human Capital in the History of Economic Thought / T. Kirian // Economy of Ukraine. - 2008. No. 9. - P. 64-73.

17. Koritski A.V. An overview of the discussion among economists of the 19th and 20th centuries on theoretical approaches to the analysis of human capital / A.V. Koritski /\% Introduction to the theory of human capital [Electronic resource]. - Access mode: http://udik.com.ua/books/ book-276 / chapter-8712/

18. Lebedeva Yu.V. Investing in human capital and economic growth / Yu.V. Lebedeva // Problems of the modern economy. - 2010. - No. 2 (34) [Electronic resource]. - Access mode: http://www.m-economy.ru/ art.php? $\mathrm{AArtId}=3083$

19. Leonova S.V. Identification and evaluation of the transformation of workers' potential in the human capital of an industrial enterprise: author's abstract. dis ... Candidate econ Sciences: speciality 08.00.04 "Economics and management of enterprises (by types of economic activity)" / S.V. Leonova; Dnipropetrovsk State University "Uzhgorod. nat un-ty ". — Uzhgorod, 2013. $-23 \mathrm{p}$.

20. Human capital of Ukraine: demographic background and socio-economic factors of formation: [col. monograph] / Ed. D.P. Melnichuk - Zhytomyr: ZHDTU, 2014 - 317 p.

21. Human capital of Ukraine: state, problems, prospects for reproduction: [monograph]: in $2 \mathrm{ch}$./ Science. Ed. VM Lich - K .: KNUBA, 2009. - Ch. 1. - 224 p.

22. Markova N. Research of tendencies of formation of intellectual components of human capital / N. Markov // Ukraine: aspects of labor. - 2005. - No. 3 .

23. Marx K. Capital / K. Marx; per. with him I.I. Stepanova-Skvortsova. - Leningrad: Pechatny Dvor, 1952. Vol. 2. -478 pp.
24. Marx K. Capital. Criticism of Political Economy / K. Marx, F. Engels // Works; transl. from 2nd ed. - K.: State Politbud URSR, 1963. - T. 23. - 847 p.

25. Marshall A. Principles of Economic Science: in 3 vols / A. Marshall. - Moscow: Progress, 1993. - Vol. 3. $226 \mathrm{pp}$.

26. Mahlup F. Production and distribution of knowledge in the USA / F. Mahlup. - Moscow: Progress, 1966. $462 \mathrm{pp}$.

27. Mill J.S. Fundamentals of political economy and some aspects of their a pplication to social philosophy: in 3 vol./ J.S. Mill - M .: Progress, 1980. - Vol. 1. - 496 pp.

28. Mikhailova L.I. Human Capital: Formation and Development in Rural Regions: [monograph] / L.I. Mikhailova - K .: Center for Educational Literature, 2008. $388 \mathrm{p}$.

29. Plotnikov I. Merkantlizm / Ed. and with the introduction art. I.S. Plotnikov - M .: Direct-Media, 2007 [Electronic resource]. - Access mode: http://www.elib.org.ua

30. Ricardo D. The Beginning of Political Economy V. Petti, A. Smith, D. Ricardo, J. Keynes, M. Fridman// Classics of Economic Thought. - Moscow: EKSMO-Press, 2000. P. 403-474.

31. Sei J.-B. Treatise on Political Economy/ J.-B. Sei // 25 key books on economics; per. fr fr A. Beyton [and others]. Chelyabinsk: Ural LTD, 1999. - 559 p.

32. Smith A. The study of the nature and causes of wealth of peoples / A. Smith // Institutional repository National Mining University of Ukraine [Electronic resource]. Access mode: http://ir.nmu. org.ua

33. Smith A. Goodwill of Nations. Studies on the nature and causes of the welfare of nations / A. Smith; per. from English. - K.: Port-Royal, 2001. - 590 p.

34. Stuart T. Wealth from The Mind: Business Bestseller/ T. Stewart; per. from english VA Nosepiece - Minsk: Paradox, 1998. - 352 p.

35. Shevchuk L.T. Loss of human capital in Ukraine: conceptual categorical apparatus and conceptual provisions / L.T. Shevchuk // Socio-economic research in the transition period. - Lviv: IRD NAS of Ukraine, 2007. Issue $3(65)$. - P. 9-27.

36. Shchetinin V.P. Human capital and ambiguity of its interpretation / V.P. Shchetinin // World Economy and International Relations. - 2001. - No. 12. - P. 42-49.

37. Yaremko I.J. Human potential as a capital of an enterprise: accounting aspect/I.J. Yaremko// Economist. - 2004. - No. 2. - P. 70-74.

38. Becker G.S. Human Capital: a theoretical and empirical analysis, with a special reference to education / G.S. Becker. - 3rd. - Chicago, The University of Chicago Press, 1993. - $390 \mathrm{p}$.

39. Bowen H.R. Investment in Human Capital and Economic Growth: Perspectives on Economic Growth / H.R. Bowen. - N.Y., 1968. - 105 p.

40. Machlup F. The Economics of Information and Human Capital/ F. Machlup. - Princeton, 1984 - 226 p.

41. McCullox J.R. The Principles of Political Economy / J.R. McCullox - AlexMurrey \& Son, 1870 [Electronic resource]. - Access mode: http://bestbook.ru

42. Menger C. Zur Theorie des Kapitals / / The Online Library of Liberty [Electronic resource]. - Access mode: http://www.webcitation. org

43. Shultz T. Investment in Human Capital./ T. Shultz. N.Y.; L., 1971. - 272 p.

44. Tnurov L. Investment in Human Capital / L. Tnurov. Belmont, 1970. - $121 \mathrm{p}$.

\section{References:}

1. Agapova, I. (1998), History of Economic Thought: A Course in Lectures, EKMOS, Moscow, Russia.

2. Antoniuk, V. (2006), "Main directions of strengthening of socio-economic foundations of human capital formation in Ukraine", Ukraine: aspects of labour, vol. 2, pp. $39-47$. 
Russia.

3. Aristotle (1976), Works: in 4 vol, Thought, Moscow,

4. Bazilevich, V. (2008), History of Economic Studies in 2 vol., vol. 1, 2nd edition., Knowledge, Kiev, Ukraine.

5. Becker,G.S. (1993), Human Capital: a theoretical and empirical analysis, with a special reference to education. The University of Chicago Press, Chicago, USA.

6. Berezin, I. (1993), Essays on the History of Economic Thought, RISK, Moscow, Russia.

7. Bogdanovski, V. (2005), "Labour and Employment in Agriculture", Issues of Economics, Vol. 6, pp. 72-83.

8. Borodin, O.(2006), "Human capital as the main source of economic grow th", Economy of Ukraine, Vol. 7. pp. $48-53$.

9. Bowen, H.R.(1968), Investment in Human Capital and Economic Growth: Perspectives on Economic Growth, N.Y.

10. Deriabina M. (2001), "Institutional Aspects of PostSocialist Transitional Period", Issues of Economics, Vol. 2, pp. $108-114$.

11. Diatlov, S. (1994), Fundamentals of the theory of human capital, Saint Petersburg, Russia.

12. Dobrynin, A. (1999), Man's productive forces: structure and forms of manifestation, Saint Petersburg, Russia.

13. Golovai, N. (2007), "Investments in human capital and wages: accounting aspect", Formation of a market economy: col. of scientific works. Special issue "Human Resources Management: Problems of Theory and Practice", vol.1, no. 1, pp. 52-65.

14. Grigorian S. (1961), Selected works of thinkers of the Middle and Middle East IX-XIV centuries, Sotsekgiz, Moscow, Russia.

15. Grishnova, O. (2001), Human Capital: Formation in the System of Education and Training, Knowledge, KOO, Kiev, Ukraine.

16. Kendrick, J.(1991), Total US Capital and its Formation, Progres, Moscow, Russia.

17. Kirian, T. (2008), "Human Capital in the History of Economic Thought", Economy of Ukraine, Vol. 9, pp. 6473.

18. Koritski, A. (2005), An overview of the discussion among economists of the 19 th and 20 th centuries on theoretical approaches to the analysis of human capital, Akademiya, Kiev, Ukraine.

19. Lebedeva, Yu. (2010), "Investing in human capital and economic growth", Problems of the modern economy, Vol. 2 (34).

20. Leonova, S.V. (2013), "Identification and evaluation of the transformation of workers' potential in the human capital of an industrial enterprise", Abstract of Ph.D. dissertation, Economics and management of enterprises, Uzhgorod. nat un-ty, Uzhgorod, Ukraine.

21. Lich, V. (2009), Human capital of Ukraine: state, problems, prospects for reproduction, KNUBA, Kyiv, Ukraine.

22. Machlup, F. (1984), The Economics of Information and Human Capital, Princeton, USA.

23. Mahlup, F. (1963), Production and distribution of knowledge in the USA, Moscow, URSR.

24. Markova, N. (2005), "Research of tendencies of formation of intellectual components of human capital", Ukraine: aspects of labor, Vol. 3, pp.34-45.

25. Marshall, A. (1993), Principles of Economic Science: in 3 vols, Progress, Moscow , Russia.

26. Marx, K (1952), Capital, Pechatny Dvor, Leningrad, Soviet Union.

27. Marx, K. (1963), Capital. Criticism of Political Economy, State Politbud, Kyiv, URSR.

28. McCullox ,J.R. (1870), The Principles of Political Economy, AlexMurrey \& Son, USA.

29. Melnichuk, D.(2014), Human capital of Ukraine: demographic background and socio-economic factors of formation, ZHDTU, Zhytomyr, Ukraine.
30. Menger, C. (1980), "Zur Theorie des Kapitals", available at: http://www.webcitation.org (Accessed 25 Nov 2018).

31. Mikhailova, L. (2008), Human Capital: Formation and Development in Rural Regions, Center for Educational Literature, Kyiv, Ukraine.

32. Mill, J.S. (1980), Fundamentals of political economy and some aspects of their application to social philosophy: in 3 vol, Progress, Moscow, URSR.

33. Mochernyi, S. (2002), Economic Encyclopedia: in 3 v., vol. 3, Akademiya, Kiev, Ukraine.

34. Plotnikov, I. (2007), Merkantlizm, Direct-Media, Moscow, Russia.

35. Ricardo, D. (2000), "The Beginning of Political Economy", Classics of Economic Thought, EKSMO-Press, Moscow, Russia.

36. Sei, J.-B. (1999), "Treatise on Political Economy", 25 key books on economics, Ural LTD, Chelyabinsk, Russia.

37. Shchetinin, V.P. (2001), "Human capital and ambiguity of its interpretation", World Economy and International Relations, Vol. 12, pp. 42-49.

38. Shevchuk, L.T. (2007), "Loss of human capital in Ukraine: conceptual categorical apparatus and conceptual provisions", Socio-economic research in the transition period, IRD NAS of Ukraine, vol. 3 (65), pp. 9-27.

39. Shultz, T. (1971), Investment in Human Capital, London, UK.

40. Smith, A. (2001), "The study of the nature and causes of wealth of peoples" Institutional repository National Mining University of Ukraine, available at: http:// ir.nmu.org.ua (Accessed 25 Nov 2018).

41. Smith, A. (2001), Goodwill of Nations. Studies on the nature and causes of the welfare of nations , Port-Royal, Kyiv, Ukraine.

42. Stuart, T. (1998), Wealth from The Mind: Business Bestseller, Paradox, Minsk, Belarusian.

43. Tnurov, L. (1970), Investment in Human Capital, London, UK.

44. Yaremko, I.J. (2004), "Human potential as a capital of an enterprise: accounting aspect", Economist, Vol. 2, pp. $70-74$.

Стаття надійщла до редакиї 02.12.2018 p. www. dy.nayka.com.ua

Електронне фахове видання

\section{ДЕРЖАВНЕЕ УПРАВЛНННЯ удосконалення та розвиток}

\section{Виходить 12 разів на рік}

\author{
Видання включено до переліку \\ наукових фахових видань України \\ 3 ДЕРЖАВНОГО УПРАВЛІННЯ
}

e-mail:economy_2008@ukr.net

тел.: (044) 223-26-28

(044) $458-10-73$ 